\title{
CORPORATE SOCIAL RESPONSIBILITY OF EXPORT ORGANIZATIONS: RELATION BETWEEN STRATEGY, ACTIVITIES AND COMMUNICATION ON FOREIGN MARKETS
}

\begin{abstract}
Andrija Barić ${ }^{1}$, Mislav Ante Omazić ${ }^{2}$ and Ana Aleksić ${ }^{2, *}$
${ }^{1}$ KONČAR - Power Plant and Electric Traction Engineering Inc.

Zagreb, Croatia

${ }^{2}$ Faculty of Economics and Business, University of Zagreb

Zagreb, Croatia

DOI: 10.7906/indecs.19.1.10

Received: 13 February 2021.

Regular article

Accepted: 27 March 2021.

ABSTRACT

The concept of corporate social responsibility has been recognized as a successful differentiation strategy for European export organizations in foreign markets. In the time of unprecedented global social, humanitarian, and economic challenges that we face today, the concept comes into the focus of most global stakeholders as never before in history. Still, the existing literature lacks a deeper analysis of differentiation on foreign markets based on corporate social responsibility. This article aims to analyse the relation between socially responsible strategy, activities and communication of export organizations in foreign markets. Empirical research was done on a sample of 78 medium and large sized Croatian export organizations. Research results reveal the importance and positive influence of inclusion of corporate social responsibility in organizational strategy on socially responsible activities and communication channels and principles in foreign markets.
\end{abstract}

\section{KEY WORDS}

corporate social responsibility, export, foreign market, CSR strategy

\section{CLASSIFICATION}

JEL: L1, M14 


\section{INTRODUCTION}

As the EU is moving strongly towards the achievement of the Sustainable Development Goals (SDGs) and Europe's climate neutrality by 2050, corporate social responsibility (CSR) becomes a necessity. In today's highly challenging business global environment, management strategic orientation on the concept of CSR becomes even more important, that the concept is strategically and operationally aligned with the social economic, ethical and moral values of the broader community [1]. As stakeholders become more and more exposed to the effects of the global online market in most industries on a daily basis, individuals' awareness of social issues is no longer local or national but global. Such a global level of awareness continually increases pressure on companies to strategically effectively implement and communicate social responsibility to all stakeholders [2].

When export organizations move beyond their domestic market, they have to comply with internationally required safety, quality, and CSR standards [3]. Moreover, they face the issue of liability of foreignness [4], as of their non-native status in the foreign market, thus CSR can help them overcome this obstacle [5]. Besides this, their CSR activities on foreign markets, can also be motivated by the fact that CSR can help create or reinforce corporate image [6], gain higher visibility, mitigate risk, have greater availability of funds, optimise ideas and increase innovative solutions for stakeholders [7].

Differentiation of products and services based on CSR, as an important element of the organizational strategy, is becoming an increasingly important factor in achieving strategic goals in foreign markets. It implies that a unique position in the market can be achieved by having a reputation of the responsible organization, offering responsible products or services, and by consideration of multiple stakeholders in organizational value chain [8]. It is necessary to ensure that the entire supply chain of the company functions in accordance with social and environmental standards [9]. Still, the question is how to design and coordinate CSR activities and multiple shareholder relations, as well as to priorities them [10].

In that existing literature, there is a scarcity of research that investigates differentiation based on CSR and how it is linked with CSR activities and communication on foreign markets. In that sense, this article aims to analyse the relation between CSR strategy, activities and communication of export organizations in foreign markets. We test for the effects of inclusion of CSR, as a crucial part of organizational strategy, on CSR activities and communication when organizations operate in host markets. The theoretical part of the article is supplemented with empirical research on a sample of 78 export organizations from Croatia. This is followed by a discussion of the main research results and implications of the conducted research.

\section{IMPORTANCE OF CORPORATE SOCIAL RESPONSIBILITY ON FOREIGN MARKETS}

Globalization and international interconnectedness of foreign markets have enabled profit and non-profit organizations, perceived in the global community as socially responsible entities, among other things, to further strengthen their competitive advantage by successfully differentiating through the concept of CSR [11]. As the range of socially responsible activities will expand daily, the management of export companies must find methods to create coherence in the strategic and operational part of CSR because it is a necessary postulate for maintaining competitive advantage in the global market and social sustainability [12]. To successfully differentiate in domestic or export markets, it is necessary to ensure that the entire supply chain of the company, but also the sales and marketing activities in the markets, 
function in accordance with social and environmental standards. In that way stakeholders, through communication with the company, successfully differentiate that kind of organization from domestic or foreign competition [13].

CSR activities are viewed as a tool that creates a positive impact of business activities on society and the environment, which in turn leads to a better reputation and higher profitability rates in different markets [14]. The concept of CSR is a perfect tool for export companies to transfer a positive reputation to foreign markets [15]. CSR creates a more positive reputation with internal and external stakeholders, ensures higher profitability rates, and attracts sophisticated and socially responsible investors [16]. As this is a process that can take several years, it is very difficult for competing companies to mimic the process of CSR differentiation efficiently and in a short time [17].

Differentiation based on social responsibility is also suitable for smaller companies because it does not require, as opposed to differentiation based on innovation or quality, a strong innovation structure and associated high costs [18]. The benefits of differentiation based on CSR, emerge as a result of consumers' willingness to pay more for products and services marketed by socially responsible organizations [19].

The most difficult task of management is to determine the financially justified limit at which investing in CSR achieves the highest financial returns because misjudging that limit will create additional costs which can steer the entity toward the abyss, both reputational and financial [20]. The greatest harm to export companies can occur if the concept of CSR is approached philanthropically or spontaneously. Only with a strategic approach based on new digital technologies does the company's management control the environmental, social, and economic line of business, regardless of whether it is a domestic or foreign market [21].

\section{CORPORATE SOCIAL RESPONSIBILTY STRATEGY ROLE IN ACTIVITIES AND COMMUNICATION IN FOREIGN MARKETS}

CSR strategy presents an agenda for managing organizational impacts on society and the environment [10], creating social and economic value, with the inseparability of these two values. It presents activities and policies unique to organizational context, and that take into consideration the needs of stakeholders and the triple bottom line of economic, social, and environmental performance $[22,23]$.

A successful differentiation in the eyes of stakeholders can be achieved when CSR strategy becomes an integral part of the company's business strategy. This strategy of differentiation through the concept of CSR is more often a logical choice because even smaller strategic investments in certain CSR activities can generate the greatest benefits through strengthening consumer loyalty who are willing to pay even higher margins to support such management policy [24]. For such loyalty and connection between the organization, consumers, and other stakeholders, it is important that management, in addition to conducting socially responsible activities, knows how to communicate the same activities transparently using primarily digital media, but also traditional media on certain markets, so that stakeholders can successfully identify with the organization and its ideas [25].

A prerequisite for successful differentiation based on CSR activities is the awareness of internal and external stakeholders about the implementation of the concept of social responsibility in business processes. In this context, the choice of communication channels for reporting on CSR activities and the content of the message to stakeholders are key factors for successful and sustainable differentiation [26]. To succeed in communicating CSR in 
domestic and foreign markets, management is required to identify target stakeholders and their interests. Furthermore, management has to develop the most effective communication channels through which dialogue with stakeholders allows management to understand which community problems are most important and sometimes even how to solve them [27]. The growing power of global stakeholders and the emergence of digital communication have created an environment in which new strategic models of approaching the concept of CSR are continuously being developed [28]. Just as profit and non-profit organizations have internationalized their operations over the past decade, stakeholders are becoming global players creating perceptions of organizations by following digital international media and social networks and increasingly rewarding socially responsible companies around the world by buying their products through online markets [29].

\section{METHODOLOGY OF RESEARCH}

\section{STUDY DESIGN AND MEASUREMENT ITEMS}

To test for the relation among CSR strategy, activities and communication of export organizations on a foreign market, empirical research was designed and conducted. Two main research propositions $(\mathrm{RP})$ were tested for:

$\mathbf{R P}_{1}$ : Inclusion of CSR in organizational strategy has a positive effect on CSR activities in foreign markets.

$\mathbf{R P}_{2}$ : Inclusion of CSR in organizational strategy has a positive effect on CSR communication in foreign markets.

A survey method and an anonymous questionnaire as a research instrument were used for data gathering.

To assess the level of inclusion of CSR in organizational strategy, a construct measuring the representation of CSR in the company's strategy was formed. This construct is based on the main dimensions of CSR as defined by ISO 260000 [30], as well as definitions of organizational strategy and its characteristics as defined by Galbreath, [31] and Tipurić [32]. By using the Likert 5-point scale ( 1 - strongly disagree, 5 - strongly agree), we asked respondents from each participating organization to evaluate their level of agreement with the provided statements.

CSR activities in foreign markets were analysed through seven dimensions defined by ISO 26000: environment, human rights, labour practices, organization governance, fair operation practices, consumer issues problems and contribution to the community and society [30]. By using the Likert 5-point scale (1-not being implemented at all, .., 5-continuously implemented), we asked respondents to rate the presence of each activity in their organization.

Communication of CSR in foreign markets was measured by the intensity of use and degree of development of communication of the export company with groups of stakeholders in foreign markets. Intensity and degree of development refer to:

- use of communication channels - four main channels of CSR communication analysed were: social responsibility reports, web pages, social networks, and advertising [33]

- development of communication assessed through the implementation of the principles of communication: 1) balance: 2) comparability, 3) accuracy; 4) timeliness; 5) clarity, and (6) reliability [34].

Each participant was asked to assess the statements referring to the level of development of each communication channel and the principles of communication by using the Likert 5-point scale $(1-$ not being implemented at all, .., 5 - continuously implemented). 


\section{SAMPLE CHARACTERISTICS}

Empirical research was sent to medium and large export companies in Croatia that had an income from their export activities at a minimum of $25 \%$ of total revenue. Sampling was done based on the data provided by the Croatian Exporters Association. Responses were obtained from 78 of the 220 companies that met the criteria. The study was conducted over a period of three weeks. In companies, the survey was answered by the owners or management of the company.

Sample characteristics are provided in Table 1.

Table 1. Sample characteristics.

\begin{tabular}{|c|c|c|c|c|c|c|c|}
\hline \multicolumn{8}{|c|}{ Size } \\
\hline \multicolumn{4}{|c|}{ Medium (50 to 250 employees) } & \multicolumn{4}{|c|}{ Large (more than 250 employees) } \\
\hline \multicolumn{4}{|c|}{$48,7 \%$} & \multicolumn{4}{|c|}{$51,3 \%$} \\
\hline \multicolumn{8}{|c|}{ Industry } \\
\hline manufacturing & \multicolumn{2}{|c|}{$\begin{array}{l}\text { wholesale and } \\
\text { retail trade }\end{array}$} & \multicolumn{2}{|c|}{$\begin{array}{c}\text { repair of motor } \\
\text { vehicles and } \\
\text { motorcycles }\end{array}$} & \multicolumn{2}{|l|}{ services } & other \\
\hline $48,7 \%$ & \multicolumn{2}{|r|}{$14,1 \%$} & \multicolumn{2}{|c|}{$14,1 \%$} & \multicolumn{2}{|l|}{$10,3 \%$} & $12,8 \%$ \\
\hline \multicolumn{8}{|c|}{ Ownership } \\
\hline domestic & \multicolumn{2}{|c|}{$<25 \%$ foreign } & \multicolumn{2}{|c|}{$25-50 \%$ foreign } & \multicolumn{2}{|c|}{$50-75 \%$ foreign } & $75 \%>$ foreign \\
\hline $59,0 \%$ & \multicolumn{2}{|r|}{$5,1 \%$} & \multicolumn{2}{|c|}{$9,0 \%$} & \multicolumn{2}{|l|}{$3,8 \%$} & $23,1 \%$ \\
\hline \multicolumn{8}{|c|}{ Market orientation } \\
\hline \multicolumn{4}{|c|}{ B2B market } & \multicolumn{4}{|c|}{$\mathrm{B} 2 \mathrm{C}$ market } \\
\hline \multicolumn{4}{|c|}{$75,6 \%$} & \multicolumn{4}{|c|}{$24,4 \%$} \\
\hline \multicolumn{8}{|c|}{ Share of exports in total revenue } \\
\hline \multicolumn{2}{|c|}{ between 21 and $40 \%$} & \multicolumn{2}{|c|}{ between 41 and $60 \%$} & \multicolumn{2}{|c|}{ between 61 and $80 \%$} & \multicolumn{2}{|c|}{ between 81 and $100 \%$} \\
\hline \multicolumn{2}{|l|}{$29,5 \%$} & \multicolumn{2}{|c|}{$19,3 \%$} & \multicolumn{2}{|c|}{$19,2 \%$} & & $32,1 \%$ \\
\hline \multicolumn{8}{|c|}{ Main export markets } \\
\hline \multicolumn{2}{|c|}{ South East Europe } & \multicolumn{2}{|c|}{ European Union } & \multicolumn{2}{|c|}{$\begin{array}{c}\text { NAFTA } \\
\text { (Canada, USA, } \\
\text { Mexico) }\end{array}$} & & Other \\
\hline $34,6 \%$ & & 46,2 & & & $5,1 \%$ & & $14,1 \%$ \\
\hline
\end{tabular}

\section{RESEARCH RESULTS}

\section{DESCRIPTIVE STATISTICS}

Results of descriptive statistics indicate respondents give on average high grades for different variables oriented towards measuring representation of CSR within the organizational strategy (Table 2). The highest average value is indicated for CSR being incorporated within company strategy as one of key strategy elements (CSR_STRATEG_1) and CSR being represented in company mission which is the key element of company strategy (CSR_STRATEG_2). 
Table 2. Descriptive statistics for variable inclusion of CSR in organizational strategy (1 strongly disagree, $\ldots, 5$ - strongly agree).

\begin{tabular}{|l|l|c|c|}
\hline \multicolumn{1}{|c|}{ Variable } & \multicolumn{1}{|c|}{ Description } & Average & St. Dev. \\
\hline CSR_STRAT_1 & $\begin{array}{l}\text { CSR is incorporated within company strategy as } \\
\text { one of the key strategy elements }\end{array}$ & 4,23 & 0,805 \\
\hline CSR_STRAT_2 & $\begin{array}{l}\text { CSR is represented in the company mission } \\
\text { which is the key element of company strategy }\end{array}$ & 4,19 & 0,722 \\
\hline CSR_STRAT_3 & $\begin{array}{l}\text { CSR is represented within the analysis of internal } \\
\text { and external influences which is the key element } \\
\text { of company strategy }\end{array}$ & 3,82 & 0,936 \\
\hline CSR_STRAT_4 & $\begin{array}{l}\text { CSR is represented within the market analysis } \\
\text { which is the key element of company strategy, }\end{array}$ & 3,69 & 0,944 \\
\hline CSR_STRAT_5 & $\begin{array}{l}\text { CSR is represented within the consumer analysis, } \\
\text { as primary stakeholders, which is the key } \\
\text { element of company strategy, }\end{array}$ & 3,85 & 0,823 \\
\hline CSR_STRAT_6 & $\begin{array}{l}\text { CSR is represented during the allocation of key } \\
\text { company resources necessary for conducting } \\
\text { socially responsible activities, }\end{array}$ & 3,71 & 0,941 \\
\hline CSR_STRAT_7 & $\begin{array}{l}\text { CSR is planned as an activity which contributes } \\
\text { to achieving competitive advantage, }\end{array}$ & 3,95 & 0,952 \\
\hline
\end{tabular}

With regard to CSR activities, results reveal export organizations on foreign markets implement different CSR activities significantly (Table 3). Mostly implemented are activities regarding labour practices (average 4,60), human rights (average 4,54), and environment (average 4,51).

Table 3. CSR activities of export organizations in foreign markets (1 - not being implemented at all, .., 5- continuously implemented).

\begin{tabular}{|l|c|c|}
\hline \multicolumn{1}{|c|}{ Variable } & Average & St. Dev. \\
\hline Organization governance & 3,95 & 1,068 \\
\hline Human right & 4,54 & 0,733 \\
\hline Labor practices & 4,60 & 0,631 \\
\hline Environment & 4,51 & 0,698 \\
\hline Fair operation practices & 4,22 & 0,832 \\
\hline Consumer issues and problems & 4,28 & 0,788 \\
\hline Contribution to the community and society & 3,92 & 0,894 \\
\hline
\end{tabular}

Table 4. CSR communication channels and principles of communication ( 1 - not being implemented at all, .., 5-continuously implemented).

\begin{tabular}{|c|l|c|c|}
\hline Dimension & \multicolumn{1}{|c|}{ Variable } & Average & St. Dev. \\
\hline \multirow{4}{*}{ Communication channels } & CSR reports & 3,81 & 1,228 \\
\cline { 2 - 4 } & Web pages & 3,68 & 1,274 \\
\cline { 2 - 4 } & Social networks & 3,23 & 1,395 \\
\cline { 2 - 4 } & Advertising & 2,69 & 1,332 \\
\hline \multirow{4}{*}{$\begin{array}{c}\text { Principles of } \\
\text { communication }\end{array}$} & Balance & 3,49 & 0,894 \\
\cline { 2 - 4 } & Comparability & 3,65 & 0,914 \\
\cline { 2 - 4 } & Accuracy & 3,86 & 0,785 \\
\cline { 2 - 4 } & Timeliness & 3,55 & 0,949 \\
\cline { 2 - 4 } & Clarity & 3,68 & 0,785 \\
\cline { 2 - 4 } & Reliability & 3,82 & 0,879 \\
\hline
\end{tabular}


Table 4 presents the CSR communication channels and principles of communication. CSR reports (average 3,81) together with web pages (average 3,68) as communication channels are mostly used. As to communication principles defined by Global Reporting Initiative (GRI) guidelines, results reveal companies in their communication are guided by principles of balance, comparability, accuracy, timeliness; clarity and reliability, as average marks for all principles are high (ranging from 3,49 to 3,86).

For further analysis sum values of construct CSR representation in organizational strategy, CSR activities, and CSR communication, have been developed and presented in table 5. Internal consistency of items within the scales, indicated their reliability, as the values of Cronbach's alpha are higher than 0,7 as recommended by Kim and Feldt [35].

Table 5. Descriptive statistics for sum values of constructs used.

\begin{tabular}{|l|c|c|c|c|}
\hline & N & Average & St. Dev. & Cronbach's Alpha \\
\hline CSR_STRAT & 78 & 3,92 & 0,66 & 0,873 \\
\hline CSR_ACTIVITY & 78 & 4,29 & 0,63 & 0,844 \\
\hline CSR_COMMUNICATION & 78 & 3,55 & 0,68 & 0,841 \\
\hline
\end{tabular}

Multicollinearity has been analysed using correlation analysis and by calculating VIF coefficients. Since none of the correlation coefficients among independent variables was lower than 0,85 , and since VIF coefficients were lower than the threshold value of 5, it was concluded that multicollinearity is not present in the dataset.

\section{TESTING OF RESEARCH PROPOSITIONS}

Our first research proposition analyses if the inclusion of CSR in organizational strategy has a positive effect on CSR activities in foreign markets. To test this, we used a regression model.

Table 6 presents a model summary of a regression model with CSR activities as a dependent variable. The adjusted coefficient of determination indicates that the model explains a $63,2 \%$ variance in dependent variable CSR activities. The Durbin-Watson coefficient is 2,007, which indicates that there is no problem with autocorrelation in the model.

Table 6. Regression model summary (dependent variable: CSR activities; independent variable: inclusion of CSR in organizational strategy).

\begin{tabular}{|c|c|c|c|c|}
\hline $\mathbf{R}$ & $\mathbf{R}$ Square & Adjusted R Square & Std. Error of the Estimate & Durbin-Watson \\
\hline 0,816 & 0,666 & 0,632 & 0,380 & 2,007 \\
\hline
\end{tabular}

Table 7. Coefficients of the regression model (dependent: CSR activities; independent variable: inclusion of CSR in organizational strategy).

\begin{tabular}{|l|c|c|c|c|c|}
\hline \multirow{2}{*}{} & \multicolumn{2}{|c|}{$\begin{array}{c}\text { Unstandardized } \\
\text { Coefficients }\end{array}$} & $\begin{array}{c}\text { Standardized } \\
\text { Coefficient }\end{array}$ & \multirow{2}{*}{ t } & \multirow{2}{*}{ Sign. } \\
\cline { 2 - 4 } & B & Std. Error & Beta & & \\
\hline (Constant) & 1,443 & 0,304 & & 4,752 & $0,000^{* * * *}$ \\
\hline CSR_STRAT_1 & 0,240 & 0,073 & 0,308 & 3,281 & $0,002^{* * *}$ \\
\hline CSR_STRAT_2 & 0,089 & 0,079 & 0,102 & 1,121 & 0,266 \\
\hline CSR_STRAT_3 & 0,168 & 0,071 & 0,251 & 2,368 & $0,021^{* *}$ \\
\hline CSR_STRAT_4 & 0,154 & 0,073 & 0,232 & 2,124 & $0,037 * *$ \\
\hline CSR_STRAT_5 & $-0,037$ & 0,065 & $-0,048$ & $-0,569$ & 0,571 \\
\hline CSR_STRAT_6 & $-0,038$ & 0,069 & $-0,057$ & $-0,552$ & 0,583 \\
\hline CSR_STRAT_7 & 0,134 & 0,061 & 0,203 & 2,186 & $0,032^{* *}$ \\
\hline
\end{tabular}

*** statistically significant with $1 \%$ probability, $* *$ statistically significant with $5 \%$ probability 
As ANOVA test has been statistically significant at the probability level of $1 \%,(F(7,70)=19,924)$ leading to the conclusion that at least one independent variable has a statistically significant impact on dependent variable CSR communication, we further tested each particular variable related to the inclusion of CSR in organizational strategy (as an independent variable) and its effect on CSR communication (dependent variable). Table 7 presents the coefficients of this regression model.

Results indicate that variables CSR_STRAT_1 (CSR is incorporated within company strategy as one of the key strategy elements), CSR_STRAT_3 (CSR is represented within the analysis of internal and external influences which is the key element of company strategy), CSR_STRAT_4 (CSR is represented within the market analysis which is the key element of company strategy) and CSR_STRAT_7 (CSR is planned as an activity which contributes to achieving competitive advantage) have a statistically significant influence on CSR activities of export organizations on foreign markets.

Our second research proposition analyzes if inclusion of CSR in organizational strategy has a positive effect on CSR communication in foreign markets.

Table 8 represents a regression model summary with CSR communication as the dependent variable. The adjusted coefficient of determination indicates that the model explains 48,3\% variance in the dependent variable CSR communication. The Durbin-Watson coefficient is 1,688 , which indicates that there is no problem for autocorrelation in the model.

Table 8. Regression model summary (Dependent variable: CSR communication; Independent variable: inclusion of CSR in organizational strategy).

\begin{tabular}{|c|c|c|c|c|}
\hline $\mathbf{R}$ & $\mathbf{R}$ Square & Adjusted R Square & Std. Error of the Estimate & Durbin-Watson \\
\hline 0,729 & 0,531 & 0,483 & 0,487 & 1,688 \\
\hline
\end{tabular}

As ANOVA test has been statistically significant at the probability level of $1 \%,(F(7,69)=11,161)$ leading to the conclusion that at least one independent variable has a statistically significant impact on dependent variable CSR communication, we further tested each particular variable related to the inclusion of CSR in organizational strategy (as an independent variable) and its effect on CSR communication (dependent variable). Table 9 presents the coefficients of this regression model.

Table 9. Coefficients of the regression model (dependent: CSR communication; independent variable: inclusion of CSR in organizational strategy).

\begin{tabular}{|l|c|c|c|c|c|}
\hline & \multicolumn{2}{|c|}{$\begin{array}{c}\text { Unstandardized } \\
\text { Coefficients }\end{array}$} & $\begin{array}{c}\text { Standardized } \\
\text { Coefficient }\end{array}$ & \multirow{2}{*}{ t } & \multirow{2}{*}{ Sign. } \\
\cline { 2 - 3 } & $\mathbf{B}$ & Std. Error & Beta & & \\
\hline Constant) & 0,618 & 0,393 & & 1,575 & 0,120 \\
\hline CSR_STRAT_1 & 0,090 & 0,094 & 0,107 & 0,959 & 0,341 \\
\hline CSR_STRAT_2 & 0,101 & 0,101 & 0,108 & 0,997 & 0,322 \\
\hline CSR_STRAT_3 & 0,147 & 0,091 & 0,202 & 1,615 & 0,111 \\
\hline CSR_STRAT_4 & 0,112 & 0,093 & 0,155 & 1,204 & 0,233 \\
\hline CSR_STRAT_5 & 0,160 & 0,083 & 0,193 & 1,925 & $0,058^{*}$ \\
\hline CSR_STRAT_6 & $-0,069$ & 0,088 & $-0,096$ & $-0,787$ & 0,434 \\
\hline CSR_STRAT_7 & 0,207 & 0,078 & 0,290 & 2,644 & $0,010^{* *}$ \\
\hline
\end{tabular}

** statistically significant with $5 \%$ probability, ${ }^{*}$ statistically significant with $10 \%$ probability

Results indicate that variables CSR_STRAT_5 (CSR is represented within the consumer analysis, as primary stakeholders, which is the key element of company strategy) and CSR_STRAT_7 (CSR is planned as an activity which contributes to achieving competitive 
advantage) have a statistically significant influence on CSR communication of export organizations on export markets.

\section{DISCUSSION AND CONCLUSION}

It is clear that modern society needs to change, how to bridge the sustainability gap through rewiring the economy becomes the most important question for modern leaders. The EU's Green Deal, a 1 trillion-euro investment plan to reduce greenhouse gas emissions by $55 \%$ in 2030 (relative to 1990 levels), has been recognized as the first comprehensive plan to achieve climate neutrality at a continental scale. As the green economy becomes a new paradigm in the EU, the struggle for stakeholder support in all industries is growing. As of the growing importance of the concept of CSR, the emergent complexity of the challenges facing the global community, but also a growing number of stakeholders, it is clear that companies operating internationally will need more financial and non-financial resources for the concept of CSR to survive on the global stage and maintain targeted profitability [24]. In addition to strategic investments in the concept of CSR, the key to entry and sustainable growth in foreign markets through differentiation based on CSR can be achieved only through dialogue and open communication with internal and external stakeholders. A one-way communication towards stakeholders can be counterproductive and jeopardize the reputation and consequently the entire investment [36].

This article was oriented towards analysis of the relation between CSR strategy, activities, and communication of export organizations. We tested for the effects of inclusion of CSR, as a crucial part of organizational strategy, on CSR activities and communication of 78 mediumsized and large export organizations from Croatia operating in foreign markets. The results of the empirical research point towards the importance and positive influence of inclusion of CSR in organizational strategy, on CSR activities and communication channels and principles in foreign markets. More specifically, when CSR is incorporated within a company strategy, when it is represented within the analysis of internal and external influences and within the market analysis but also when CSR is planned as an activity that contributes to achieving competitive advantage this can have a statistically significant influence on CSR activities of export organizations on foreign markets. Also, results show, that regarding communication channels and principles, when CSR is represented within the consumer analysis, and when CSR is planned as an activity that contributes to achieving competitive advantage this has a statistically significant influence on CSR communication of export organizations on foreign markets.

However, results have to be seen in the light of research limitations, primarily relating to sample size and its characteristics, such as the inclusion of only medium and large-sized organizations from Croatia. Furthermore, many mediating and moderating variables can affect the CSR behaviour of export organizations on the foreign markets which were not included in this research. For instance, it would be interesting to see if specifics of foreign market itself, such as its regulatory framework can have a higher effect on the level and type of CSR activities and communication on a foreign market. Also, to further understand the behaviour of export organisations in terms of their CSR, it would be interesting to compare its CSR behaviour on the both domestic and export markets.

Despite these limitations, it can be concluded that this article provided some additional insight into the relationship between the inclusion of CSR in organizational strategy on CSR activities and communication channels and principles in foreign markets. And that research results can be seen as a starting point for further research on this subject. It has to be emphasized that the growing focus of consumers on the concept of CSR can be considered a global phenomenon that in the upcoming years will be even more important, and 
consequently continue to be an increasingly important topic for top management of companies operating globally, regardless of industry or domicile market [37, 38]. Therefore, additional research is necessary. Not only financial benefits but also new market opportunities, in both domestic and foreign markets, long - term business profitability and continued stability are expected for companies that will know how to incorporate CSR in their organizational strategy and take into consideration the needs of their internal and external stakeholders [29], activities and communication.

\section{REFERENCES}

[1] O’Connor, A. and Meister, M.: Corporate social responsibility attribute rankings. Public Relations Review 34(1), 49-50, 2008, http://dx.doi.org/10.1016/j.pubrev.2007.11.004,

[2] Di Giuli, A. and Kostovetsky, L.: Are red or blue companies more likely to go green? Politics and corporate social responsibility.

Journal of Financial Economics 111(1), 158-180, 2014, http://dx.doi.org/10.1016/j.jfineco.2013.10.002,

[3] Reis, G.G. and Molento, C.F.M.: Emerging market multinationals and international corporate social responsibility standards: bringing animals to the fore. Journal of Business Ethics 166(2), 351-368, 2020, http://dx.doi.org/10.1007/s10551-019-04144-5,

[4] Campbell, J.T.; Eden, L. and Miller, S.R.: Multinationals and corporate social responsibility in host countries: Does distance matter?

Journal of International Business Studies 43(1), 84-106, 2012, http://dx.doi.org/10.1057/jibs.2011.45,

[5] Bai, X.; Chang, J. and Li, J.J.: How do international joint ventures build legitimacy effectively in emerging economies? CSR, political ties, or both?

Management International Review 59(3), 387-412, 2019, http://dx.doi.org/10.1007/s11575-019-00382-x,

[6] Zyglidopoulos, S.; Williamson, P. and Symeou, P.: The corporate social performance of developing country multinationals.

Business Ethics Quarterly 26(3), 379-406, 2016,

http://dx.doi.org/10.1017/beq.2016.41,

[7] Godos-Díez, J.L.: Cabeza-García, L. and Fernández-González, C.: Relationship between corporate social responsibility (CSR) and internationalisation strategies: a descriptive study in the Spanish context.

Administrative Sciences 8(4), 57, 2018, http://dx.doi.org/10.3390/admsci8040057,

[8] Cruz, L.B.; Boehe, D.M. and Ogasavara, M.H.: CSR-based differentiation strategy of export firms from developing countries: An exploratory study of the strategy tripod.

Business \& Society 54(6), 723-762, 2015, http://dx.doi.org/10.1177/0007650312473728,

[9] Boehe, D.M. and Cruz, L.B.: Corporate social responsibility, product differentiation strategy and export performance.

Journal of Business Ethics 91(2), 325-346, 2010, http://dx.doi.org/10.1007/s10551-010-0613-z,

[10] Markota Vukić, N. et al.: Leadership for Sustainability: Connecting Corporate Responsibility Reporting and Strategy.

In: Doğru, C.: Leadership Styles, Innovation, and Social Entrepreneurship in the Era of Digitalization. IGI Global, pp.44-72, 2020, 
[11]Lee, C.K. et al.: The impact of CSR on casino employees' organizational trust, job satisfaction, and customer orientation: an empirical examination of responsible gambling strategies.

International Journal of Hospitality Management 33(1), 406-415, 2013, http://dx.doi.org/10.1016/j.ijhm.2012.10.011,

[12] Lim, J.S. and Greenwood, C.A.: Communicating corporate social responsibility (CSR): Stakeholder responsiveness and engagement strategy to achieve CSR goals.

Public Relations Review 43(4), 768-776, 2017, http://dx.doi.org/10.1016/j.pubrev.2017.06.007,

[13] Chun, S. and Cho, E.: Differentiation strategy, CSR, and real activities earnings management: Evidence from Korea.

Journal of Applied Business Research (JABR) 33(4), 669-692, 2017, http://dx.doi.org/10.19030/jabr.v33i4.9988,

[14] Kanji, G.K. and Chopra, P.K.: Corporate social responsibility in a global economy. Total Quality Management 21(2), 119-143, 2010, http://dx.doi.org/10.1080/14783360903549808,

[15] Gjoberg, M.: The origin of corporate social responsibility: Global forces or national legacies? Socio-economic Review 7(4), 605-637, 2009, http://dx.doi.org/10.1093/ser/mwp017,

[16] Beardsell, D.J.: The influence of CSR disclosure on corporate governance and company performance.

SMC Working paper, 2008, http://dx.doi.org/10.2139/ssrn.1302314,

[17]Cruz, L.B. and Boehe, D.M.: CSR in the global market place: Towards sustainable global value chains.

Management Decision 8(46), 1187-1209, 2008, http://dx.doi.org/10.1108/00251740810901381,

[18] Boulouta, I. and Pitelis, C.N.: Who needs CSR? The impact of corporate social responsibility on national competitiveness.

Journal of Business Ethics 119(3), 349-364, 2014, http://dx.doi.org/10.1007/s10551-013-1633-2,

[19] Reinhardt, F.L. Environmental product differentiation: Implications for corporate strategy.

California Management Review 40(4), 43-73, 1998, http://dx.doi.org/10.2307/41165964,

[20] Samet, M. and Jarboui, A.: How does corporate social responsibility contribute to investment efficiency?

Journal of Multinational Financial Management 40(C), 33-46, 2017, http://dx.doi.org/10.1016/j.mulfin.2017.05.007,

[21] Marques-Mendes, A. and Santos, M.J.: Strategic CSR: an integrative model for analysis. Social Responsibility Journal 12(2), 363-381, 2016, http://dx.doi.org/10.1108/SRJ-04-2015-0055,

[22] Aguinis, H.: Organizational responsibility: Doing good and doing well. In: Zedeck, S. ed.: APA handbook of industrial and organizational psychology. American Psychological Association, Washington, DC, pp.855-879, 2011,

[23] Aguinis, H. and Glavas, A.: What we know and don't know about corporate social responsibility: A review and research agenda.

Journal of Management 38(4), 932-968, 2012, http://dx.doi.org/10.1177/0149206311436079,

[24] Li, J.; Zhang, F. and Sun, S.: Building consumer-oriented CSR differentiation strategy. Sustainability 11(3), 664, 2019, http://dx.doi.org/10.3390/su11030664, 
[25] Kim, S.: The process model of corporate social responsibility (CSR) communication: CSR communication and its relationship with consumers' CSR knowledge, trust, and corporate reputation perception.

Journal of Business Ethics 154(4), 1143-1159, 2019, http://dx.doi.org/10.1007/s10551-017-3433-6,

[26] McWilliams, A. and Siegel, D.S.: Corporate social responsibility: a theory of firm perspective.

The Academy of Management Review 26(1), 117-127, 2001, http://dx.doi.org/10.5465/amr.2001.4011987,

[27] Golob, U. and Podnar, K.: Corporate social responsibility communication and dialogue. In: Ihlen, Ø.; Bartlett, J.L. and May, S., eds.: The Handbook of Communication and Corporate Social Responsibility.

Wiley, New York, pp.231-251, 2011,

[28]Cho, C.H.; Phillips, J.R.; Hageman, A.M. and Patten, D.M.: Media richness, user trust, and perceptions of corporate social responsibility.

Accounting, Auditing \& Accountability Journal 22(6), 933-952, 2009, http://dx.doi.org/10.1108/09513570910980481,

[29] Anastasiadou, E.; Lindh, C. and Vasse, T.: Are consumers international? A study of CSR, cross-border shopping, commitment and purchase intent among online consumers. Journal of Global Marketing 32(4), 239-254, 2009, http://dx.doi.org/10.1080/08911762.2018.1528652,

[30] ISO: Guidance on social responsibility, International Standard, ISO/FDIS 26000. ISO, Geneva, 2010,

[31] Galbreath, J.: Building corporate social responsibility into strategy. European Business Review 21(2), 109-127, 2008, http://dx.doi.org/10.1108/09555340910940123,

[32] Tipurić, D.: Iluzija strategije - Razotkrivanje socijalno konstruirane zbilje poduzeća. In Croatian.

Sinergija nakladništvo, Zagreb, 2014.

[33]Birth, G.; Illia, L.; Lurati, F. and Zamparini, A.: Communicating CSR: Practices among Switzerland's top 300 companies.

Corporate Communications 13(2), 182-196, 2008, http://dx.doi.org/10.1108/13563280810869604,

[34] Global Reporting Initiative (GRI): Sustainability Reporting Guidelines. GRI, Boston, MA, 2002,

[35] Kim, S. and Feldt, L.S.: A comparison of tests for equality of two or more independent alpha coefficients.

Journal of Educational Measurement 45(2), 179-193, 2008, http://dx.doi.org/10.1111/j.1745-3984.2008.00059.x,

[36]Zhao, Z.; Meng, F.; He, Y. and Gu, Z.: The influence of corporate social responsibility on competitive advantage with multiple mediations from social capital and dynamic capabilities.

Sustainability 11(1), 218, 2019, http://dx.doi.org/10.3390/su11010218,

[37] Marin, L.; Martín, P.J. and Rubio, A.: Doing good and different! The mediation effect of innovation and investment on the influence of CSR on competitiveness.

Corporate social responsibility and environmental management 24(2), 159-171, 2017, http://dx.doi.org/10.1002/csr.1412,

[38] Roblek, V.; Pejić Bach, M.; Meško, M. and Kresal, F.: Corporate social responsibility and challenges for corporate sustainability in first part of the $21^{\text {st }}$ century.

Cambio. Rivista sulle trasformazioni sociali 9(19), 31-46, 2020,

http://dx.doi:10.13128/cambio-8486. 